\title{
PENGGUNAAN BIOCHAR DAN MOL BONGGOL PISANG UNTUK PERBAIKAN KUALITAS BIBIT TANAMAN PISANG (Musa paradisiaca $\mathrm{L}$ ).
}

\author{
Yohana Merci Belit, Amir Hamzah*, Reza Dwi Julianto Prakoso \\ Fakultas Pertanian Universitas Tribhuwana Tunggadewi \\ Jl. Telaga Warna, Tlogomas, Malang, 65144. \\ *E-mail: amir.hamzah@unitri.ac.id
}

Direvisi: 23/06/2021

Disetujui: 23/06/2021

\begin{abstract}
ABSTRAK
Selama ini dalam budidaya pisang, petani hanya mengandalkan bibit dari anakan yang tumbuh dari pangkal pisang. Hal tersebut menyebabkan produk pisang tidak optimal. Salah satu solusi yang dapat dilakukan adalah dengan menggunakan biochar dan Mikro Organisme Lokal (MOL) dari bonggol pisang untuk perbaikan kualitas bibit tanaman pisang. Kedua bahan ini merupakan potensi sumberdaya alam yang selama ini masih belum banyak dimanfaatkan untuk memperbaiki mutu bibit pisang. Kombinasi biochar dan MOL bonggol pisang diharapkan mampu menghasilkan bibit tanaman pisang yang berkualitas baik. Penelitian ini bertujuan untuk mendapatkan dosis biochar dan MOL bonggol pisang yang tepat untuk pembibitan pisang. Hasil analisis sidik ragam menunjukkan tidak ada perbedaan yang siginifikan pada kombinasi perlakuan pemberian biochar dan MOL bonggol pisang (B) dengan umur anakan bonggol pisang (P) pada semua parameter pengamatan. Perlakuan anakan bonggol pisang terbaik terdapat pada perlakuan anakan bonggol umur dewasa (P2) karena berpengaruh hampir pada semua parameter yang diamati. Perlakuan pemberian biochar dan MOL bonggol pisang (B) pada semua parameter tidak berbeda nyata, namun secara terpisah perlakuan pemberian tanah + MOL $200 \mathrm{cc} /$ liter air (B5) menunjukkan perbedaan pertumbuhan yang lebih baik dibandingkan dengan perlakuan lain.
\end{abstract}

Kata kunci: Biochar, biomol, bibit pisang

\section{ABSTRACT}

Currently, farmers planted bananas only relying on seedlings from saplings growing from the base of bananas causing production not optimum. One of the solutions is to use biochar and local micro organism (MOL) from banana excrescence. These two materials are abundant and have not been widely utilized in order to improve the quality of banana seedlings. Combination of biochar and MOL banana excrescence are expected to produce good quality of banana seeds. This research aims to obtain a proper dose of biochar and $M O L$ for breeding bananas. The analysis of variance showed that the combination treatment of biochar and MOL Banana excrescence $(B)$ do not significantly affect to the age of banana seedlings $(P)$ on all observation parameters. The best banana seedlings treatment is found in the treatment of adult age (P2) saplings because it affects almost all the observed parameters. The treatment of biochar and MOL of Banana excrescence (B) on all parameters are not significantly different, but in different treatment adding soil and MOL $200 \mathrm{cc} / L$. (B5) shows a better in growth compared to other treatments 
Keywords: Biochar; banana excrescence; MOL; seed; quality.

\section{PENDAHULUAN}

Pisang (Musa paradisiaca L.) merupakan salah satu tanaman pangan hortikultura yang banyak di budidayakan di Indonesia. Pisang termasuk komoditas buah-buahan prioritas di Indonesia. Tahun 2014 tanaman pisang juga menempati peringkat pertama untuk produksi buah dengan produksi mencapai 6,8 juta ton yang memberikan kontribusi terbesar terhadap produksi buah nasional, sedangkan tahun 2015 produksinya mencapai 7,3 juta ton (Kementerian Pertanian, 2016). Komoditas ini juga termasuk salah satu yang dicanangkan oleh Kementerian Riset dan Teknologi untuk dikembangkan di Indonesia. Pertimbangannya bahwa pisang merupakan komoditas berorientasi kerakyatan yang mampu meningkatkan kesejahteraan petani (Kasutjianingati dan Boer, 2013). Seiring dengan meningkatnya jumlah penduduk, pendapatan dan kesadaran akan manfaat buah sebagai sumber karbohidrat, vitamin dan mineral maka konsumsi pisang mengalami peningkatan dari waktu ke waktu. Selain itu pisang juga merupakan salah satu komoditas yang berpeluang besar untuk dikembangkan sebagai diversifikasi pangan di Indonesia.

Pengembangan tanaman untuk mencukupi kebutuhan harus diimbangi dengan peningkatan produksi. Salah satu kendala terbesar untuk mendapatkan produksi pisang yang berkualitas baik adalah penyediaan bibit. Rendahnya produktivitas pisang terjadi akibat teknik pembibitan dan budidaya tanaman yang belum memadai, serangan hama dan penyakit, dan minimnya bibit yang tersedia. Di tingkat petani, pembibitan pisang masih terbatas pada penggunaan tanaman dewasa. Cara ini sebenarnya relatif mudah dan cukup sederhana, namun sangat boros karena menggunakan bibit dalam jumlah banyak (Supriana et al, 2015). Ketersediaan dan penggunaan bibit pisang yang sehat saat ini masih terbatas. Bibit pisang yang biasa digunakan sebagian besar berasal dari anakan pisang itu sendiri tanpa adanya sentuhan teknologi. Akibatnya buah yang diperoleh semakin hari semakin kecil. Salah satu upaya untuk mendapatkan bibit pisang yang mempunyai kualitas baik adalah dengan menggunakan biochar dan Mikro organisme lokal (MOL).

Biochar merupakan bahan pembenah tanah yang dihasilkan dari proses pembakaran tidak sempurna (pirolisis). Biochar memiliki kapasitas tukar kation tinggi dan memiliki $\mathrm{pH}$ basa. Biochar sangat potensial untuk meningkatkan aktivitas biologis tanah, meningkatkan karbon tanah dan memperbaiki kualitas tanah untuk meningkatkan produksi pertanian (Lehmann et al, 2011; PazFerreiro dan $\mathrm{Fu}, 2013)$. Liu et al., (2013) mengungkapkan bahwa perbaikan hasil tanaman setelah penambahan biochar sering dikaitkan dengan peningkatan kadar air dan retensi nutrisi. Selain itu biochar juga mampu meningkatkan sifat biologis dan KTK tanah, serta berdampak pada peningkatan nutrisi dan perbaikan $\mathrm{pH}$ tanah. Potensi yang demikian mampu meningkatkan pertumbuhan bibit tanaman pisang. Selain biochar, penggunaan mikro organisme lokal (MOL) juga memiliki peranan penting untuk pertumbuhan tanaman.

Salah satu bagian penting dari pisang yang selama ini tidak dimanfaatkan adalah bagian bonggol. Beberapa hasil penelitian mengungkapkan bahwa bonggol pisang ternyata mengandung nutrisi yang lengkap (Kesumaningwati, 2015). Kandungan yang terdapat di dalamnya adalah karbohidrat sebesar $66 \%$, pati $45,4 \%$ dan kadar protein $4,35 \%$. Selain itu juga mengandung mikrobia pengurai. Mikrobia pengurai tersebut terletak pada bonggol pisang bagian luar maupun bagian dalam (Marsiningsih et al., 2015). Jenis 
mikrobia yang telah teridentifikasi pada MOL bonggol pisang antara lain Bacillus $s p$. , Aeromonas sp., danAspergillus nigger. Mikroba inilah yang biasa mendekomposisi bahan organik. Berdasarkan hal tersebut maka penggunaan MOL bonggol pisang yang dikombinasi dengan biochar akan mampu meningkatkan pertumbuhan dan kualitas bibit tanaman pisang secara berkelanjutan. Penelitian ini bertujuan untuk mendapatkan dosis biochar dan MOL bonggol pisang yang tepat untuk pembibitan pisang.

\section{METODE}

Penelitian ini dilaksanakan di kebun percobaan Fakultas Pertanian Universitas Tribhuwana Tunggadewi, pada ketinggian $\pm 450 \mathrm{~m}$ dpl. Penelitian ini dilaksanakan selama 6 bulan. Peralatan yang digunakan pada pelaksanaan penelitian meliputi: cangkul, polybag dengan ukuran $10 \mathrm{~kg}$, parang, gembor dan ember, gelas ukur, timbangan, kertas label, penggaris, kamera dan alat tulis. Bahan yang digunakan pada penelitian ini antara lain bibit pisang yang berasal dari 3 umur yang berbeda, biochar, MOL, dan tanah, pupuk kandang.

Penelitian ini menggunakan Rancangan Acak Kelompok (RAK) dengan 2 faktor. Faktor pertama terdiri dari: Faktor 1. Anakan dari bonggol pisang $(\mathrm{P}): \mathrm{P} 1=$ Anakan dari bonggol pisang umur pedang, $\mathrm{P} 2=$ Anakan dari bonggol pisang umur dewasa, P3 = Anakan dari bonggol pisang umur berbuah, $\mathrm{B} 1=$ Kontrol (tanpa kombinasi), B2 $=$ Tanah + biochar dosis 20 ton/ha, B3 = Tanah + biochar dosis 30 ton/ha, B4 = Tanah + MOL $100 \mathrm{cc} /$ liter air, B5 = Tanah + MOL dari bonggol pisang $200 \mathrm{cc} /$ liter air, B6 = Tanah + Biochar dosis 20 ton/ha + MOL bonggol pisang $100 \mathrm{cc} /$ liter air, B7 = Tanah + Biochar dosis 30 ton/ha + MOL bonggol pisang $200 \mathrm{cc} / \mathrm{liter}$ air. Percobaan diulang sebanyak 3 kali, masing-masing perlakuan terdiri dari 3 polybag, sehingga keseluruhan percobaan berjumlah 7 × 3 x
$3 \times 3=189$ polybag percobaan. Parameter yang diamati meliputi; saat tumbuh tunas, tinggi tanaman, jumlah daun , luas daun dan diameter batang. Data hasil pengamatan dianalisis Anova dan analisis diskriptif untuk melihat masingmasing perlakuan,

\section{HASIL DAN PEMBAHASAN}

\section{Awal Muncul Tunas}

Hasil pengamatan waktu/saat awal muncul tunas menunjukkan bahwa ketiga jenis asal bibit yang berasal dari bonggol pisang yang masih anakan, bonggol pisang pedang dan bonggol pisang dewasa. Perbedaan ini terlihat dari kecepatan tumbuh munculnya tunas dari masing-masing perlakuan. Perlakuan penggunaan anakan pisang yang bersumber dari bonggol pisang yang masih anakan dengan perlakuan penggunaan dosis biochar dan MOL menunjukan bahwa penggunaan biochar dosis 30 ton ha-1 dengan MOL $200 \mathrm{cc}^{-1}$ liter air (P1B7) memperlihatkan waktu tumbuh lebih cepat. Waktu tumbuh pada perlakuan P1B7 saat muncul tunas ratarata pada umur 34,33 hari setelah tanam (HST). Kecepatan tumbuh berikutnya adalah perlakuan tanah dengan $200 \mathrm{cc}^{-1}$ liter air, tumbuh rata-rata pada umur 39,56 hari. Hal sebaliknya terlihat pada perlakuan tanah dengan dosis biochar 20 ton $\mathrm{ha}^{-1}$, rata-rata tumbuh pada umur 59 HST (Gambar 1).

Hal ini menunjukan bahwa penggunaan umur bibit dan mikroorganisme lokal (MOL) sangat berpengaruh terhadap kecepatan tumbuh atau munculnya tunas. Hal yang paling menonjol terlihat pada penggunaan dosis MOL $200 \mathrm{cc}^{-1}$ liter air berpengaruh terhadap kecepatan munculnya tunas. Kecepatan tumbuh diduga berasal dari beberapa unsur yang terkandung di dalam bonggol pisang. Marsiningsih et al., (2015), melaporkan bahwa di dalam bonggol pisang terdapat beberapa mikroba yang berfungsi sebagai perombak. Selain itu juga terdapat 
beberapa kandungan hara yang terkandung di dalamnya yaitu karbohidrat, pati dan protein. Hal ini sangat berbeda dengan penggunaan bonggol pisang anakan pedang dan bonggol pisang dewasa sebagai sumber bibit. Perbedaan ini terlihat pada gambar 2 dan 3 yang memiliki kecepatan tumbuh yang berbeda.

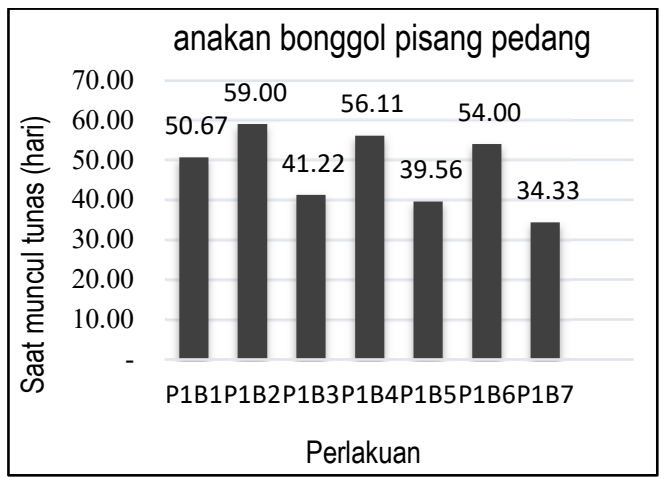

Gambar 1. Waktu yang diperlukan untuk muncul tunas pada anakan bonggol pisang umur pedang

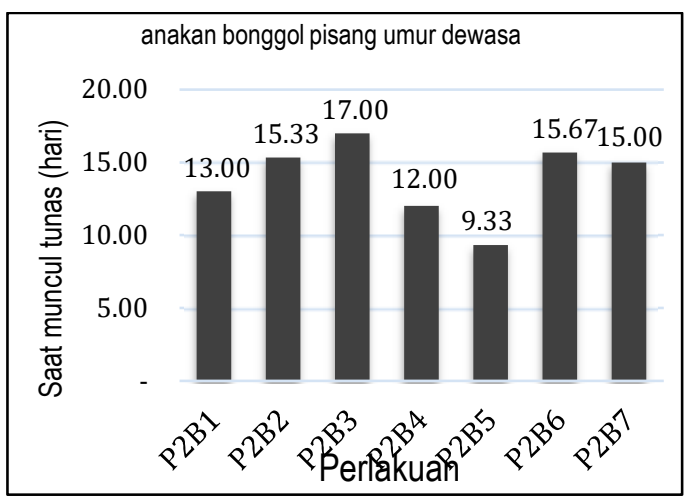

Gambar 2. Waktu yang diperlukan untuk muncul tunas pada anakan bonggol pisang umur dewasa

Pada penggunaan anakan bonggol pisang umur pedang perlakuan penggunaan biochar dan MOL menunjukan bahwa perlakuan tanah dengan MOL dosis $200 \mathrm{cc}^{-1}$ liter air (P2B5) rata-rata tumbuh pada umur 9,33 HST, sedangkan pada perlakuan tanah dengan biochar dosis 30 ton $\mathrm{ha}^{-1}$ menunjukan saat tumbuh tunas paling lama yaitu 17 hari setelah tanam (HST). Hal yang sama terlihat pada perlakuan bonggol pisang umur dewasa. Saat muncul tunas paling cepat terlihat pada perlakuan tanah dengan MOL $200 \mathrm{cc}^{-1}$ liter air. Rata-rata kecepatan tumbuhnya pada hari ke 11,67, sedangkan kecepatan tumbuh paling lama terdapat pada perlakuan dosis biochar 30 ton ha ${ }^{-1}$ yang dikombinasi dengan MOL $200 \mathrm{cc} \mathrm{liter}^{-1}$. Dengan demikian ketiga sumber bibit dengan dosis MOL $200 \mathrm{cc}^{-1}$ liter air mampu mempercepat pertumbuhan tunas pisang. Sebaliknya penggunaan biochar belum mampu mempercepat keluarnya tunas. Jika dilihat dari ketiga sumber bibit, maka sumber bibit yang berasal dari anak pedang dan dewasa lebih cepat tumbuh tunas, dibandingkan bibit yang berasal dari bonggol yang masih kecil atau masih anakan.

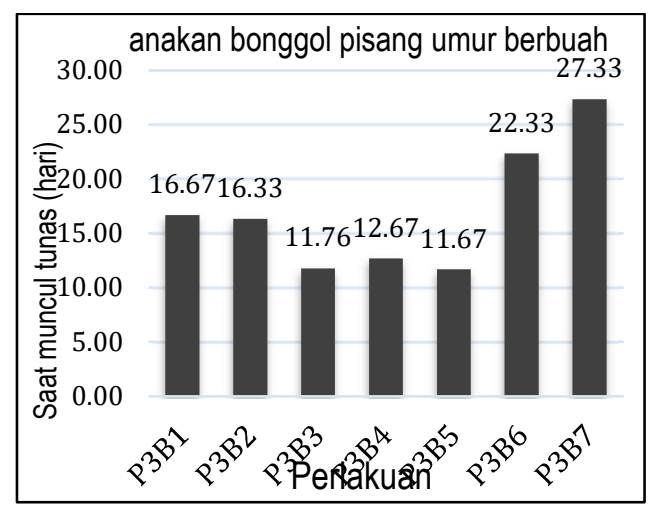

Gambar 3. Waktu yang diperlukan untuk muncul tunas pada anakan bonggol pisang umur berbuah

Pada gambar diatas terlihat bahwa penggunaan biochar belum mampu mempercepat keluarnya tunas walaupun dikombinasi dengan MOL. Lamanya keluar tunas pada perlakuan biochar diduga belum tersedia sehingga belum memberi efek terhadap kecepatan keluarnya tunas. Beberapa peneliti mengungkapkan bahwa penggunaan biochar sangat efektif dalam jangka panjang, sedangkan jangka pendek karena proses penguraian membutuhkan waktu yang sangat panjang. Noviani et al., (2018) mengungkapkan bahwa biochar merupakan bahan pembenah tanah yang memiliki karbon hitam cukup tinggi. Tingginya karbon di dalam tanah 
mengakibtakan sangat sulit untuk terdekomposisi dan membutuhkan waktu yang lama. Namun penelitian yang dilakukan oleh Nigussie et al., (2012) melaporkan bahwa aplikasi biochar yang berasal dari bonggol jagung dengan dosis 10 ton $\mathrm{ha}^{-1}$ mampu meningkatkan $\mathrm{pH}$ tanah secara signifikan, Begitu juga Corganik, P-tersedia, N-total, dan KTK. Peningkatan ini terjadi karena biochar mengandung senyawa-senyawa yang dibutuhkan tanaman, memiliki luas permukaan yang tinggi, porositas yang tinggi, serta kandungan abu dalam biochar yang secara tidak langsung dapat melarutkan senyawa-senyawa yang terjerap seperti $\mathrm{Ca}, \mathrm{K}$, dan $\mathrm{N}$ yang dibutuhkan oleh tanaman.

\section{Pertumbuhan Tanaman Pisang}

Tabel 1. Pengaruh Pemberian Biochar dan MOL Bonggol Pisang Terhadap Rata-Rata

\begin{tabular}{|c|c|c|c|c|}
\hline \multirow{2}{*}{ Perlakuan } & \multicolumn{4}{|c|}{ Tinggi Tanaman (cm) } \\
\hline & 4 MST & $8 \mathrm{MST}$ & $12 \mathrm{MST}$ & $16 \mathrm{MST}$ \\
\hline $\begin{array}{l}\text { Anakan bonggol pisang umur pedang } \\
\text { (P1) }\end{array}$ & $19.00 \mathrm{~b}$ & $48.94 \mathrm{a}$ & 87.97 a & $110.81 \mathrm{a}$ \\
\hline $\begin{array}{l}\text { Anakan bonggol pisang umur dewasa } \\
\text { (P2) }\end{array}$ & $21.60 \mathrm{~b}$ & $59.44 \mathrm{~b}$ & $105.39 \mathrm{~b}$ & $128.79 \mathrm{~b}$ \\
\hline $\begin{array}{l}\text { Anakan bonggol pisang umur berbuah } \\
\text { (P3) }\end{array}$ & $15.76 \mathrm{a}$ & $41.46 \mathrm{a}$ & $82.70 \mathrm{a}$ & $103.46 \mathrm{a}$ \\
\hline BNT 5\% & 3.20 & 9.40 & 16.16 & 19.21 \\
\hline \multicolumn{5}{|l|}{ Biochar dan MOL Bonggol Pisang } \\
\hline B1 = Kontrol ( tanpa kombinasi) & 17.11 & 44.57 & 80.50 & 101.30 \\
\hline $\mathrm{B} 2=$ Tanah + biochar dosis 20 ton $/$ ha & 20.63 & 42.37 & 78.92 & 107.26 \\
\hline $\mathrm{B} 3=$ Tanah + biochar dosis 30 ton $/$ ha & 16.70 & 53.26 & 101.57 & 124.07 \\
\hline B4 $=$ Tanah + MOL 100cc/liter airir & 15.39 & 50.61 & 84.74 & 102.00 \\
\hline $\begin{array}{l}\mathrm{B} 5=\text { Tanah }+ \text { MOL } 200 \mathrm{cc} / \text { liter air } \\
\mathrm{B} 6=\text { Biochar } 20 \text { ton } / \mathrm{ha}+\mathrm{MOL}\end{array}$ & 22.30 & 59.69 & 113.33 & 135.19 \\
\hline 100cc/liter air & 19.76 & 43.65 & 86.17 & 107.22 \\
\hline $\begin{array}{l}\text { B7 = Biochar } 30 \text { ton } / \text { ha }+ \text { MOL 200cc/ } \\
\text { liter air }\end{array}$ & 19.61 & 55.47 & 98.89 & 123.44 \\
\hline BNT 5\% & \multicolumn{4}{|c|}{ tn } \\
\hline \multicolumn{5}{|c|}{$\begin{array}{r}\text { Keterangan : Angka yang diikuti huruf yang sama pada kolom yang sama tidak berbeda } \\
\text { nyata pada taraf uji BNT } 5 \% \text {, tn : tidak nyata, MST (Minggu Setelah Tanam) }\end{array}$} \\
\hline $\begin{array}{l}\text { Penggunaan anakan bonggol pisang } \\
\text { dewasa diduga mempunyai pertumbuhan }\end{array}$ & \multicolumn{4}{|c|}{$\begin{array}{l}\text { tunas lateral yang optimal, didukung oleh } \\
\text { dominansi apikal yang rendah dan kulit }\end{array}$} \\
\hline
\end{tabular}

Keterangan : Angka yang diikuti huruf yang sama pada kolom yang sama tidak berbeda nyata pada taraf uji BNT 5\%, tn : tidak nyata, MST (Minggu Setelah Tanam)

Penggunaan anakan bonggol pisang dewasa diduga mempunyai pertumbuhan
Hasil penelitian menunjukkan tidak terdapat pengaruh nyata antara perlakuan anakan umur bonggol pisang dengan aplikasi biochar + MOL dari bonggol pisang terhadap parameter tinggi tanaman, tetapi perlakuan perbedaan umur anakan bonggol pisang mampu memberikan pengaruh nyata pada parameter tinggi tanaman disemua umur pengamatan. Umur pengamatan 4 minggu setelah tanam (MST) pada perlakuan anakan umur bonggol pisang dewasa rata-rata tinggi tanaman sebesar $21,60 \mathrm{~cm}$, berbeda nyata dengan perlakuan anakan bonggol pisang berbuah yaitu sebesar $15,76 \mathrm{~cm}$. tetapi tidak berbeda nyata dengan perlakan anakan umur bonggol pisang pedang. Secara terpisah perlakuan tanah + MOL $200 \mathrm{cc} /$ liter air memberikan pertumbuhan pada masing-masing umur $4,8,12$, dan 16 MST masing-masing sebesar 22.30; 59.69; 113,33; dan 135,19 (Tabel 1).

\section{Tinggi Tanaman Pisang}


bonggol yang sedang (tidak terlalu tebal). Pada umur anakan bonggol pisang pedang dan berbunga. Hal ini diakibatkan pertumbuhan tunas lateral yang kurang optimal akibat dominansi apikal yang tinggi pada saat umur anakan pedang dan anakan umur berbunga. Terhambatnya pertumbuhan tunas lateral disebabkan adanya dominasi apikal yang tinggi. Kulit bonggol yang tebal pada anakan pisang berbuah mampu menghambat dari pertumbuhan pembentukan tunas (Sugito, 2012).

Rendahnya nilai tinggi tanaman pada perlakuan anakan bonggol pisang berbunga diakibatkan oleh kandungan sitokinin yang rendah. Keadaan ini akan menyebabkan tunas mengalami dorman. Akibatnya akan terbentuk hormon etilen karena organ-organ yang ada sudah tua. Hasil penelitian ini masih lebih baik dari penelitian Ratna et al. (2006), yang mendapatkan tinggi tunas hanya sebesar $27,27 \mathrm{~cm}$ dengan menggunakan anakan bonggol pisang yang belum berbuah (berbunga). Sementara penelitian dari Irwanto (2013) yang menggunakan bonggol pisang berbunga (berbuah) hanya mendapatkan tinggi tanaman sebesar 12,30 cm. Hal yang sama terdapat juga pada parameter jumlah daun, dimana daun tertinggi terdapat pada perlakuan anakan umur bonggol pisang dewasa (P2) (Tabel 2).

Tabel 2. Pengaruh Pemberian Biochar dan MOL Bonggol Pisang Terhadap rata-rata Jumlah Daun pada Tanaman Pisang

\begin{tabular}{|c|c|c|c|c|}
\hline \multirow[b]{2}{*}{ Perlakuan } & \multicolumn{4}{|c|}{ Jumlah Daun (helai) } \\
\hline & 4 MST & 8 MST & $\begin{array}{c}12 \\
\text { MST }\end{array}$ & $\begin{array}{c}16 \\
\text { MST }\end{array}$ \\
\hline $\begin{array}{l}\text { Anakan bonggol pisang umur pedang } \\
\text { (P1) }\end{array}$ & $1.60 \mathrm{~b}$ & $4.95 \mathrm{~b}$ & $5.57 \mathrm{~b}$ & $5.71 \mathrm{~b}$ \\
\hline $\begin{array}{l}\text { Anakan bonggol pisang umur dewasa } \\
\text { (P2) }\end{array}$ & $2.13 \mathrm{c}$ & $5.52 \mathrm{~b}$ & $5.84 \mathrm{~b}$ & $6.06 \mathrm{~b}$ \\
\hline Anakan bonggol pisang umur berbuah (P3) & $0.92 \mathrm{a}$ & $3.49 \mathrm{a}$ & $4.59 \mathrm{a}$ & $4.83 \mathrm{a}$ \\
\hline BNT 5\% & 0.49 & 0.86 & 0.82 & 0.85 \\
\hline \multicolumn{5}{|l|}{ Biochar dan MOL Bonggol Pisang } \\
\hline B1 = Kontrol ( tanpa kombinasi) & 1.96 & 4.37 & 4.85 & 4.78 \\
\hline $\mathrm{B} 2=$ Tanah + biochar dosis 20 ton $/$ ha & 1.00 & 3.93 & 4.67 & 5.22 \\
\hline $\mathrm{B} 3=$ Tanah + biochar dosis 30 ton $/$ ha & 1.63 & 4.89 & 5.44 & 5.70 \\
\hline B4 $=$ Tanah + MOL 100cc/liter air & 1.00 & 4.22 & 4.81 & 5.37 \\
\hline B5 $=$ Tanah + MOL 200cc/liter air & 1.93 & 5.30 & 6.00 & 6.26 \\
\hline $\begin{array}{l}\text { B6 = Biochar } 20 \text { ton } / \text { ha }+ \text { MOL } 100 \mathrm{cc} / \text { liter } \\
\text { air } \\
\text { B7 }=\text { Biochar } 30 \text { ton } / \text { ha }+ \text { MOL } 200 \mathrm{cc} / \text { liter }\end{array}$ & 1.59 & 4.93 & 5.56 & 5.33 \\
\hline air & 1.74 & 4.96 & 6.00 & 6.07 \\
\hline
\end{tabular}

Keterangan: Angka yang diikuti huruf yang sama pada kolom yang sama tidak berbeda nyata pada taraf uji BNT 5\%, tn : tidak nyata, MST (Minggu Setelah Tanam)

Perlakuan anakan bonggol pisang umur dewasa pada pengamatan umur 8 16 MST (Tabel 2) memiliki rata-rata jumlah daun antara 5,52 sampai 6,06 helai. Jika dibandingkan dengan perlakuan penggunaan anakan lain, pada anakan umur bonggol pisang dewasa diduga memiliki tingkat pembentukan hormon sitokinin dan auksin yang optimal sehingga memicu pertumbuhan tanaman. Hormon sitokinin dan auksin sangat berperan dalam proses pertumbuhan vegetatif tanaman (Muhadi, 2016). Lebih lanjut dikatakan bahwa tanaman yang umurnya sudah tua akan lebih banyak mengandung zat beracun 
serta etilen sehingga mengganggu pertumbuhan tanaman. Adanya hormon etilen pada tanaman akan menghambat pemanjangan akar dan batang tanaman.

Perlakuan biochar dan MOL bonggol pisang tidak menunjukkan adanya perbedaan yang nyata diantara perlakuan, tetapi perlakuan tanah + MOL $200 \mathrm{cc} / \mathrm{L}$ air mempunyai nilai rata-rata jumlah daun terbanyak pada semua umur pengamatan 4-16 MST (Tabel 2). Perlakuan MOL mampu meningkatkan pertumbuhan anakan tanaman pisang lebih cepat dibandingkan dengan aplikasi biochar. Hal ini dikarenakan karakteristik yang berbeda. MOL merupakan pupuk sedangkan biochar berperan sebagai pembenah tanah. MOL akan lebih efektif diserap oleh tanaman karena lebih cepat tersedia. MOL merupakan pupuk organik cair berasal dari hasil fermentasi sehingga cepat tersedia bagi tanaman. Menurut Purwasasmita (2009) larutaan MOL mengandung berbagai unsur hara mikro dan makro serta juga mempunyai kandungan bakteri sebagai perangsang pertumbuhan tanaman. Perombak bahan organik tanah akan lebih cepat. Kandungan unsur hara MOL bonggol pisang berkisar antara $0,48 \% \mathrm{~N}, 0,05 \% \mathrm{P}$, dan $0,17 \%$ K (Suhastyo, 2011).

Biochar merupakan sebagai bahan pembenah tanah yang potensial digunakan untuk meningkatkan kualitas lahan. Kapasitas Tukar Kation (KTK) dan $\mathrm{pH}$ tanah dapat ditingkatkan dengan aplikasi biochar. Menurut Novak et al (2009), penggunaan biochar mampu meminimalisir pencucian kation $\mathrm{K}^{+}$dan $\mathrm{Nh}_{4}{ }^{+}$. Hasil penelitian Nurida (2014), penggunaan biochar dalam waktu satu musim tanam belum mampu meningkatkan N, P, dan karbon tanah. Penggunaan biochar mampu meningkatkan daya ikat air (Glaser et al, 2002; Chan et al, 2007). Ketersediaan air yang meningkat di dalam tanah akan berdampak terhadap peningkatan pertumbuhana tanaman.

Selain parameter tinggi tanaman dan jumlah daun, parameter luas daun dan diameter batang pun mengalami hal yang sama. Penggunaan anakan bonggol pisang dewasa (P2) mampu meningkatkan pertumbuhan luas daun dan diameter batang tertinggi. Parameter luas daun berada pada kisaran 25,09 sampai 372,35 dibanding perlakuan lain, sedangkan penggunaan biochar + MOL tertinggi pada perlakuan tanah + MOL 20 cc/l air yang berada pada kisaran 26,03 427,06 (Tabel 3). Hal yang sama juga terlihat pada parameter diameter batang. Parameter diameter batang terlihat bahwa perlakuan anakan bonggol pisang dewasa (P2) berada pada kisaran 7 sampai 24 $\mathrm{mm}$. Sedangkan pada perlakuan biochar + MOL, nilai tertinggi terdapat pada perlakuan tanah + MOL $200 \mathrm{cc} / 1$ air yaitu antara 8,22 sampai 26,02 (Tabel 4). Hal ini menunjukan bahwa penggunaan anakan bonggol pisang dan biochar + MOL pada perlakuan tersebut mampu menopang pertumbuhan tanaman (Tabel 3 dan 4). Kecepatan pertumbuhan luas daun tanaman dipicu oleh adanya efektifitas dalam proses fotosintesis. Proses fotosintesis akan menghasilkan produk berupa fotosintat yang sangat dipengaruhi terhadap pertumbuhan luas daun tanaman. Semakin besar luas daun maka proses fotosintesis akan berlangsung secara optimal.

Tabel 3. Pengaruh Pemberian Biochar dan MOL Bonggol Pisang Terhadap Rata-Rata Luas Daun pada Tanaman Pisang 


\begin{tabular}{lcccc}
\hline & 4 MST & 8 MST & 12 MST & 16 MST \\
\hline $\begin{array}{l}\text { Anakan bonggol pisang umur pedang } \\
\text { (P1) }\end{array}$ & $23.00 \mathrm{a}$ & $109.18 \mathrm{a}$ & $238.82 \mathrm{a}$ & $328.67 \mathrm{a}$ \\
$\begin{array}{l}\text { Anakan bonggol pisang umur dewasa } \\
\text { (P2) }\end{array}$ & $25.09 \mathrm{~b}$ & $129.19 \mathrm{~b}$ & $284.97 \mathrm{~b}$ & $372.35 \mathrm{~b}$ \\
$\begin{array}{l}\text { Anakan bonggol pisang umur berbuah } \\
\text { (P3) }\end{array}$ & $15.61 \mathrm{a}$ & $94.78 \mathrm{a}$ & $202.02 \mathrm{a}$ & $291.08 \mathrm{a}$ \\
\hline BNT 5\% & $\mathbf{7 . 8 6}$ & $\mathbf{3 3 . 3 5}$ & $\mathbf{6 1 . 2 6}$ & $\mathbf{8 0 . 5 5}$ \\
\hline Biochar dan MOL Bonggol Pisang & & & & \\
\hline B1 = Kontrol (tanpa kombinasi) & 21.34 & 99.12 & 202.34 & 283.89 \\
B2 = Tanah + biochar dosis 20 ton/ha & 15.16 & 84.32 & 189.27 & 278.33 \\
B3 = Tanah + biochar dosis 30 ton/ha & 23.44 & 141.93 & 277.22 & 395.41 \\
B4 = Tanah + MOL 100cc/liter air & 13.11 & 106.63 & 214.98 & 278.67 \\
B5 = Tanah + MOL 200cc/liter air & 26.03 & 146.89 & 339.53 & 427.06 \\
B6 = Biochar 20 ton/ha+MOL & 24.71 & 84.46 & 206.95 & 306.27 \\
100cc/liter air & & & & \\
B7 = Biochar 30 ton /ha+MOL & 24.85 & 114.00 & 263.24 & 325.66 \\
200cc/liter air & & & & \\
\hline
\end{tabular}

BNT 5\% tn

Keterangan: Angka yang diikuti huruf yang sama pada kolom yang sama tidak berbeda nyata pada taraf uji BNT 5\%, tn : tidak nyata, MST (Minggu Setelah Tanam)

Tabel 4. Pengaruh Pemberian Biochar dan MOL Bonggol Pisang Terhadap Rata-Rata Diameter Batang pada Pohon Pisang

\begin{tabular}{|c|c|c|c|c|}
\hline \multirow{2}{*}{ Perlakuan } & \multicolumn{4}{|c|}{ Diameter Batang ( mm) } \\
\hline & 4 MST & 8 MST & 12 MST & 16 MST \\
\hline Anakan bonggol pisang umur pedang & 5.95 & & & \\
\hline (P1) & $\mathrm{ab}$ & $11.41 \mathrm{a}$ & $18.45 \mathrm{a}$ & $20.95 \mathrm{ab}$ \\
\hline $\begin{array}{l}\text { Anakan bonggol pisang umur dewasa } \\
\text { (P2) }\end{array}$ & $7.05 \mathrm{~b}$ & $14.24 \mathrm{~b}$ & $21.45 \mathrm{~b}$ & $24.00 \mathrm{~b}$ \\
\hline $\begin{array}{l}\text { Anakan bonggol pisang umur berbuah } \\
\text { (P3) }\end{array}$ & $4.40 \mathrm{a}$ & $10.15 \mathrm{a}$ & $16.85 \mathrm{a}$ & $19.17 \mathrm{a}$ \\
\hline BNT 5\% & 1.78 & 2.01 & 2.81 & 3.77 \\
\hline \multicolumn{5}{|l|}{ Biochar dan MOL Bonggol Pisang } \\
\hline B1 = Kontrol ( tanpa kombinasi) & 5.95 & 11.80 & 18.77 & 19.30 \\
\hline $\mathrm{B} 2=$ Tanah + biochar dosis 20 ton $/$ ha & 4.31 & 9.75 & 16.26 & 19.05 \\
\hline $\mathrm{B} 3=$ Tanah + biochar dosis 30 ton $/$ ha & 5.65 & 12.53 & 20.23 & 22.44 \\
\hline B4 $=$ Tanah + MOL 100cc/liter air & 4.70 & 11.68 & 18.64 & 20.84 \\
\hline $\begin{array}{l}\mathrm{B} 5=\text { Tanah }+ \text { MOL } 200 \mathrm{cc} / \text { liter air } \\
\text { B6 }=\text { Biochar } 20 \text { ton } / \text { ha }+ \text { MOL }\end{array}$ & 8.22 & 13.67 & 22.17 & 26.02 \\
\hline $\begin{array}{l}\text { B6 = B 10char } 2 \\
100 \mathrm{cc} / \text { liter air } \\
\text { B7 = Biochar } 3\end{array}$ & 5.37 & 10.90 & 17.35 & 20.11 \\
\hline $\begin{array}{l}\text { B7 = Biochar } 30 \text { ton } / \mathrm{ha}+\mathrm{MOL} \\
\text { 200cc/liter air }\end{array}$ & 6.38 & 13.20 & 19.02 & 21.85 \\
\hline
\end{tabular}

Keterangan : Angka yang diikuti huruf yang sama pada kolom yang sama tidak berbeda nyata pada taraf uji BNT 5\%, tn : tidak nyata, MST (Minggu Setelah Tanam)

Energi yang dihasilkan oleh tanaman bergantung pada nisbah rasio ekternal dan internal daun. Daun yang panjang dan lebar akan mudah menyerap cahaya sehingga fotosintesis menjadi lebih tinggi (Sayekti, et al., 2012). Permukaan daun yang luas akan menyebabkan peningkatan jumlah dan ukuran klorofil 
yang terdapat pada jaringan palisade dan spons parenkim. Semakin optimal proses fotosintesis maka akan berdampak terhadap meningkatnya produksi tanaman. Khodijah et al. (2018) memperlihatkan luas daun mempunyai peran yang cukup banyak dalam meningkatnya penambahan bobot total tanaman dengan nilai koefisiesn determinasi $\left(r^{2}\right)$ sebesar $86,4 \%$. Banyaknya jumlah daun yang terbentuk berarti luas daun menjadi lebih lebar. Kemampuan daun dalam menerima cahaya untuk proses fotosintesis menjadi lebih besar dalam menghasilkan karbohidrat dan akan ditranslokasikan keseluruh jaringan tanaman. Translokasi hasil fotosintesis ini akan mempengaruhi juga diameter batang.

Pada sisi lain, penggunaan biochar pada penelitian ini belum terlihat secara signifikan. Walaupun beberapa peneliti mengungkapkan bahwa penggunaan biochar mampu memperbaiki sifat fisik, kimia dan biologi tanah. Pengaruh biochar terhadap pertumbuhan tanaman belum nampak pada musim tanam pertama, tetapi biochar mempunyai kemampuan menyimpan air untuk pertumbuhan tanaman. Biochar merupakan jenis arang hayati yang berfungsi untuk memperbaiki struktur kimia dan fisika tanah. Arang mempunyai kemampuan menahan air tinggi, teksturnya remah, siklus udata dan KTK tinggi (Syahrul, 2014). Biochar yang dibenamkan kedalam tanah akan mampu menyimpan karbon secara stabil selama ribuan tahun. Namun Steiner et al (2008) menyatakan bahwa pengaruh biochar dan pemupukan akan dapat terlihat setelah musim tanam ke tiga.

Perbaikan kualitas tanah menggunakan biochar harus mempunyai implikasi terhadap peningkatan pertumbuhan tanaman. Beberapa hasil penelitian telah menunjukkan adanya peningkatan produktivitas tanam akibat pemberian biochar meskipun peningkatan yang ada masih sangat bervariasi. Pada tanah Alfisol yang tergolong jenis tanah cukup baik, hanya mampu meningkatkan $6,27 \%$ pada tanaman produktivitas padi gogo (Haefele et al. 2011). Sementara hasil penelitian lain menunjukkan adanya peningkatan mencapai 14,29\%-32,14\%. Peningkatan produktivitas jagung akibat pemberian biochar sangat signifikan yaitu yaitu mencapai 52,43\% (Nurida et al. 2012). Sedangkan jika pada kondisi lahan kering iklim kering sekitar 57,5595,20 (Dariah et al. 2013). Efektivitas pemberian biochar terhadap produktivitas tanaman sangat tergantung pada karaketistik sifat biochar, dosis yang digunakan, dan jenis tanaman yang diusahakan.

\section{SIMPULAN}

1. Hasil analisis sidik ragam menunjukkan tidak adanya perbedaan yang siginifikan pada kombinasi perlakuan pemberian biochar dan MOL bonggol pisang (B) dengan umur anakan bonggol pisang (P) pada semua parameter pengamatan.

2. Perlakuan anakan bonggol pisang terbaik terdapat pada perlakuan anakan bonggol umur dewasa (P2) karena memberikan pengaruh yang nyata hampir pada semua parameter yang diamati .

3. Perlakuan pemberian biochar dan MOL bonggol pisang (B) pada semua parameter tidak berbeda nyata, namun secara terpisah perlakuan pemberian tanah + MOL 200 cc/L.air (B5) menunjukan perbedaan pertumbuhan yang lebih baik dibandingkan dengan perlakuan lain.

\section{UCAPAN TERIMA KASIH}

Ucapan terima kasih disampaikan kepada PT. Indofood Sukses Makmur, Tbk., yang telah membiayai penelitian ini dalam Program bantuan penelitian mahasiswa tugas akhir berupa Indofood 
Riset Nugraha (IRN) tahun 2020. Terima kasih yang sama disampaikan kepada Fakultas Pertanian Universitas Tribhuwana Tunggadewi yang telah memfasilitasi penelitian ini.

\section{DAFTAR PUSTAKA}

Chan, K.Y., Zwieten, B,L. avn., Meszaros, I., Downie, D., dan Joseph, S. 2007. Agronomic values of greenwaste biochar as a soil amendment. Australian Journal of Soil Research, 2007, 629-634

Dariah, A., N.L. Nurida dan Sutono. 2013. The effect of biochar on soil quality and maize production in upland in dry climate region. In Proceeding 11th international Conference the East and Southeast Asia federation of Soil Science Societies. Bogor, Indonesia

Glaser, B., Lehmann, J., dan Zech, W.2002. Ameliorating physical and chemical properties of highly weathered soils in the tropics with charcoal: A Review. Biol Fertil Soils, 35:219-230

Haefele M, Konboon Y, Wongboon W, Amarante S, Maarifat A, Pfeiffer M, Knoblauch C (2011) Effects and fate of biochar from rice residues in rice-based systems. Field Crops Research, 121, 430- 440

Irwanto. 2013. Pengaruh Kompos terhadap Pertumbuhan Bibit Pisang Asal Bonggol/Bit. Widyaiswara Pertama, Jambi.

Kementerian Pertanian. 2016. Statistik Pertanian. Kementerian Pertanian. Jakarta. http//:kementan.org.id

Kasutjianingati dan D. Boer. 2013. Mikropropagasi pisang mas kirana (Musa acuminate L.) Memanfaatkan BAP dan NAA secara in vitro. Jurnal Agroteknos 3(1): 60-64.

Kesumaningwati R., 2015. Penggunaan MOL Bonggol Pisang (Musa paradisiaca) Sebagai Dekomposer Untuk Pengomposan Tandan Kosong Kelapa Sawit.Jurnal Ziraa'ah Volume 40 Nomor 1, Pebruari
Khodijah, N.S., Suwignyo, R.A., Harun, M.U., dan Robiartini, L. 2018. Hubungan Luas Daun Terhadap Pertambahan Berat Kering Rumput Gajah di Berbagai Perlakuan di Media Tailing Timah. Jurnal Agroekotek 10 (1) : $36-44$.

Lehmann, J., Rillig, M. C., Thies, J., Masiello, C. A., Hockaday, W. C., dan Crowley, D. 2011. Biochar effects on soil biota, a review, Soil Biol. Biochem., 43 : 1812-1836.

Liu, X., Zhang, A., Ji, C., Joseph, S., Bian, R., Li, L., Pan, G., dan PazFerreiro, J. 2013. Biochar's effect on crop productivity and the dependence on experimental conditions - a metaanalysis of literature data, Plant Soil, 373 : 583-594, doi:10.1007/s11104013-1806-x.

Muhadi I., 2016. Pengaruh pemberian hormon naftalen acetyl acyd (naa) dan kinetin pada kultur jaringan nanas bogor (Ananas comosus (1.) Merr.) Cv. Queen. Bio-site. Vol. 02 No. 2, November 2016 : 1-50. file:///C:/Users/ACER/Downloads/34 11-Article\%20Text-6835-1-1020161219.pdf

Nurida, N.L. A. Rachman, dan Sutono. 2012. Potensi pembenah tanah biochar dalam pemulihan tanah terdegradasi dan peningkatan hasil jagung pada Typic Kanhapludults, Lampung. Buana Sains. 12(1):69-74.

Nurida, N. L. 2014. Potensi Pemanfaatan Biochar dan Rehabilitasi Lahan Kering di Indonesia. Peneliti Badan Litbang Pertanian Di Balai Penelitian Tanah. Bogor

Novak, J.M., Busscher,W.J., Laird, D.L., Ahmedna,M., Watts, D.W., Niandou, M.A.S., 2009. Impact of biochar amendment on fertility of a southeastern coastal plain soil. Soil Science174, 105 -112.

Marsiningsih N.W., Suwastika A.A.N.G., Sutari N.W.S., 2015. Analisis Kualitas Larutan MOL (Mikroorganisme Lokal) Berbasis Ampas Tahu. Jurnal Agroekoteknologi Tropika. Volume 
4,

No.

3. http://ojs.unud.ac.id/index.php/jat

Nigussie, A., Kissi, E., Misganaw, M., dan Ambaw, G. 2012. Effect of biochar application on soil properties and nutrient uptake of lettuces (Lactuca sativa) grown in chromium polluted soils. American-Eurasian J. Agric. \& Environ. Sci., 12 (3): 369 376.

Paz-Ferreiro, J. dan Fu, S. 2013. Biological indices for soil quality evaluation: perspectives and limi tations, Land Degrad. Develop., doi:10.1002/ldr.2262.

Purwasasmita, M. 2009. Mikroorganisme Lokal sebagai Pemicu Siklus Kehidupan dalam Bioreaktor Tanaman. Seminar Nasional Teknik Kimia. Bandung 19-20 Oktober 2009. Indonesia. Jakarta.

Ratna, T., Awaludin, dan A. Susanto. 2006. Pengaruh Media terhadap Pertumbuhan Bibit Pisang Susu Asal Bonggol di Sambelia, Lombok Timur NTB. Hortikultura. 10(1)15-22

Rotundo J.L., Martin R., Ragular, 2004. Vertical seed distribution in the soil constrains regeneration of Bromus pictus in a Patagonian steppe. Journal of Vegetation Science Vol. 15 No. 4, 2004. https://doi.org/10.1111/j.16541103.2004.tb02290.x

Sayekti, R., S.Djoko, P., dan Toekidjo. 2012. Karakterisasi Delapan Aksesi Kacang Tunggak (Vigna unguiculata L.Walp) Asal Daerah Istimewa Yogyakarta.Jurnal Penelitian Vol 1 No.1, 2012.
Steiner, C., B. Glaser, W. G. Teixeira, J. Lehmann, W. E. H. Blum, dan W. Zech. 2008. Nitrogen Retention and Plant Uptake on a Highly Weathered Central Amazonian Ferralsol ammended with Compost and Charcoal. Journal of Plant Nutrition and Soil Science.

Suhastyo, A.A. 2011. Studi Mikrobiologi dan Sifat Kimia Mikroorganisme Lokal yang Digunakan pada Budidaya Padi Metode SRI (System of Rice Intensification).. Institut Pertanian Bogor. Bogor

Sugito, I. 2012. Aplikasi Rizobakteri Pemacu Pertumbuhan Tanaman dalam Pertumbuhan Bibit Pisang (Musa paradisiaca, Linn)

Supriana I.K.A., Wijaya G., dan Raka I.G.N., 2015. Pengaruh Sumber Bonggol dan Media Tanam pada Pembibitan Tanaman Pisang Kayu (Musa paradisiaca L.cv.Kayu). Jurnal Agroekoteknologi Tropika, Vol. 4, No. 2, April 2015. http://ojs.unud.ac.id/index.php/JAT

Syahrul. 2014. Pengaruh mikoriza dan biochar terhadap pertumbuhan dan hasil tanaman kacang tanah (Arachis hypogeal L.) pada tanah kritis. Fakultas Pertanian Universitas Syiah Kuala. Banda aceh.

Noviani P.I., Slamet S., dan Citraresmini A., 2018. Kontribusi Kompos JeramiBiochar Dalam Peningkatan PTersedia, Jumlah Populasi BPF dan Hasil Padi Sawah. Jurnal Ilmiah Aplikasi Isotop dan Radiasi. Vol. 14 No. 1 Juni 2018 
Jurnal Agrosains dan Teknologi Volume 3 No. 1 Juni 2018 website : jurnal.umj.ac.id/index.php/ftan
P-ISSN 2528-0201

e-ISSN 2528-3278 